\title{
PRINSIP-PRINSIP UMUM REKRUTMEN POLITIK SEBAGAI LANDASAN IDIL PENYUSUNAN POLA REKRUTMEN DALAM AD/ART PARTAI POLITIK DI INDONESIA
}

\author{
Else Suhaimi \\ elsehadi@gmail.com \\ Fakultas Hukum Universitas Tamansiswa Palembang
}

\begin{abstract}
Abstrak Rekrutmen politik merupakan salah satu fungsi strategis yang diberikan kepada partai politik. Tujuan rekrutmen politik untuk menyeleksi atau memilih kandidat yang akan ditawarkan ke masyarakat pada saat pemilihan umum sebagai calon anggota legislatif, calon presiden dan calon wakil presiden, calon kepala daerah dan calon wakil kepala daerah. Menurut Pasal 29 UU No. 2 Tahun 2011 mengatur bahwa rekrutmen dilaksanakan melalui seleksi kaderisasi secara demokratis sesuai dengan AD/ART partai dengan mempertimbangkan paling sedikit $30 \%$ keterwakilan perempuan belum sepenuhnya sesuai harapan, sehingga rekrutmen selama ini dilakukan melalui pendekatan-pendekatan pragmatis belaka. Untuk memudahkan pelaksanaan rekrutmen politik tersebut diperlukan prinsip-prinsip yang akan menjadi landasan ideal bagi partai politik untuk menyusun metode atau mekanisme rekrutmen politik dalam AD/ART partai politik mereka. Fungsi AD/ART dijadikan sebagai landasan yuridis bagi partai politik sebagaimana yang diamanatkan undang-undang. Adapun prinsip-prinsip tersebut antara lain; prinsip ketokohan, prinsip kemanfaatan/kepentingan bersama, prinsip ideologis, prinsip perimbangan suara, prinsip demokrasi, prinsip keterbukaan, prinsip keadilan dan prinsip kesetaraan.
\end{abstract}

Kata kunci: partai politik, rekrutmen politik, prinsip-prinsip

\begin{abstract}
Political recruitment is one of the strategic functions assigned to political parties. The purpose is to select or decide on contenders to be offered to the public as legislative, president and vice president, regional head and regional deputy head candidates in the course of general election. The provision of Article 29 of Law No. 2 Year 2011 requires the recruitment to be carried out through democratic regeneration selection in line with the political party's articles of association/bylaws, and by taking into account of at least 30\% women's representation. However, the implementation is not entirely in line with expectations, seeing that the recruitments, up to this day, were carried out merely using pragmatic approaches. To facilitate the progress of political recruitment, there should be principles outlined as the ideal foundation for political parties to develop methods or mechanisms of political recruitment in their articles of association/bylaws. The articles of association/bylaws must be functioned as a legal basis for political parties as mandated by law. The required principles are including the principles of persona, benefit/common interest, ideology, votes balance, democracy, transparency, justice and equality.
\end{abstract}

Keywords: political party, political recruitment, principles

\section{PENDAHULUAN}

Sebagaimana amanat Pasal 2 ayat (1) UUD RI 1945 yang menyatakan, "Kedaulatan berada di tangan rayat dilaksanakan menurut Undang-undang Dasar". Dalam rumusan tersebut, semua lembaga negara baik secara langsung ataupun tidak langsung dianggap sebagai pelaksana kedaulatan rakyat, yang diharuskan 
melaksanakan tugasnya menurut ketentuan undang-undang dasar, tidak hanya satu lembaga, melainkan semua lembaga negara diharuskan pula bekerja menurut ketentuan undang-undang dasar. ${ }^{1}$

Kedaulatan rakyat tersebut merupakan ruh demokrasi. Melalui demokrasi, kedaulatan rakyat diwujudkan dalam bentuk mengikutsertakan rakyat dalam pergantian kepemimpinan secara normal. Ada dua pola keikutsertaan rakyat tersebut yaitu melalui Pemilu dan melalui lembaga perwakilan rakyat.

Pemilu sebagaimana yang diatur dalam pasal 22E UUD RI Tahun 1945 dilaksanakan secara langsung, umum, bebas, rahasia, jujur dan adil setiap lima tahun sekali. Pemilihan umum diselenggarakan untuk memilih anggota Dewan Perwakilan Rakyat, Dewan Perwakilan Daerah, Presiden dan Wakil Presiden, dan Dewan Perwakilan Rakyat Daerah dan pemilihan kepala daerah.

Penyelenggaraan demokrasi langsung Indonesia hanya terbatas pada penentuaan pejabat tersebut akan tetapi yang berkaitan dengan aspirasi pembentukan aturan hukum dilakukan melalui dewan perwakilan yaitu Dewan Perwakilan Rakyat Republik Indonesia (DPR RI) dan Dewan Perwakilan Rakyat Daerah (DPRD).

Dalam penyelenggaraan demokrasi langsung terdapat peran strategis konstitusional yaitu menyiapkan calon pejabat yang akan di pilih dalam Pemilu. Peran strategis itu diberikan kepada partai politik dan merupakan satu-satunya pihak yang bertanggung jawab dalam penyediaan calon pejabat publik yang akan dipilih pada pemilihan baik pemilihan anggota legislatif, pemilihan presiden dan wakil presiden dan pemilihan kepala daerah.

Posisi yang demikian strategis menempatkan partai politik sebagai kunci institusi demokrasi perwakilan (representative democracy) baik dalam proses pembentukan maupun penyelenggaraan pemerintahan negara. Atas fungsi itu, secara konseptual partai politik dipandang sebagai salah satu institusi demokrasi hlm.292.

${ }^{1}$ Listiyono Santoso, dkk, (de) Konstruksi Ideologi Negara, 2003, ning-Rat, Jogjakarta, 


\section{Jurnal Tripantang}

Falkultas Hukum Universitas Tamansiswa Palembang

yang diharapkan dapat menopang terbentuknya pemerintahan yang stabil dan demokratis, meskipun pada kenyataannya tidak jarang justru terjadi sebaliknya. ${ }^{2}$

Dalam Ilmu Politik, partai politik merupakan sekelompok anggota yang terorganisasi secara rapi dan stabil yang disatukan dan didorong oleh suatu ideologi tertentu, yang berusaha mencari dan mempertahankan kekuasaan dalam pemerintahan lewat pemilihan umum guna melaksanakan kebijaksanaan umum dan sarana pengintegrasian masyarakat, serta saluran partisipasi masyarakat dalam proses politik. $^{3}$

Peraturan perundang-undangan tentang partai politik terdapat hal yang menarik untuk dikaji adalah pasal yang mengatur tentang fungsi dari partai politik tersebut khususnya fungsi rekrutmen politik. Di panggung perpolitikan di Indonesia, keberadaan partai politik mengalami perkembangan yang pesat dari segi jumlah, dan ideologi yang diusung. Akan tetapi jumlah Parpol yang banyak tersebut hanyat terlihat ada jika akan terjadi event-event kenegaraan seperti Pemilu, Pilpres dan Pilkada. Pada saat menjelang event partai politik kelihatan sangat sibuk. Partai politik sibuk untuk mencari sosok yang akan diusung. Demi dapatnya sosok yang akan diusung, partai politik melakukan lobi-lobi dan manuver-manuver politik.

Kesibukan-kesibukan itu dikarenakan lemahnya sistem rekrutmen dan pola kaderisasi anggota partai politik. Sehingga ketika akan mempersiapkan calon pejabat yang akan dipilih oleh masyarakat Parpol tidak punya calon yang dipersiapkan melalui proses pengkaderan. Tidak terdapatnya sistem kriteriaisasi calon. Akhirnya yang terjadi adalah munculnya calon-calon karena faktor-faktor tertentu seperti faktor ketokohan, pengaruh "dinasti politik" dan "mahar politik".

Di satu sisi partai politik juga menghadapi maraknya fenomena "naturalisasi" kader partai politik dari satu partai ke partai lain sebagai akibat lemahnya sistem rekrutmen dan pola kaderisasi tersebut yang memprihatinkan. ${ }^{4}$

${ }^{2}$ Firdaus, Desain Stabilitas Pemerintahan Demokrasi \& Sistem Kepartaian, Yrama Widya, Bandung, 2015, Hlm. 11

3 Elly M.Setiadi \& Usman Kolip, Pengantar Sosiologi Politik, 2013, Kencana Prenadamedia Group, Jakarta, hlm. 279

${ }^{4}$ Muhadam Labolo dan Teguh Ilham, Partai Politik dan Sistem Pemilihan Umum di Indonesia Teori, Konsep dan Isu Strategis, PT RajaGrafindo Persada, Jakarta, 2015 , hlm.197 
Lemahnya rekrutmen politik oleh partai politik menyangkut juga masalah fundraising (pengumpulan dana). Ketika sebuah partai menghadapi krisis dalam hal pendanaan maka kemungkinan segala macam cara akan dilakukan termasuk dengan menggadaikan ideologi partai, hal ini dikarenakan biaya Pemilu yang mahal, maka jalan satu-satunya partai politik memanfaatkan kadernya yang memiliki posisi strategis dalam jabatan politik untuk mengumpulkan dana secara illegal dan berusaha untuk menjadikannya seolah-olah legal. Tidak heran jika ada institusi atau badan usaha Negara yang disebut sebagai 'sapi perah'. Realitas tersebut tentunya sangat mengancam keuangan negara dan menjelekan citra partai politik yang bersangkutan. ${ }^{5}$

Pada era reformasi sebanyak 48 partai peserta pemilu ikut meramaikan pesta demokrasi terbesar tersebut. Jumlah partai yang sangat banyak di satu sisi mencerminkan semangat demokrasi namun di sisi lain juga menimbulkan gejala yang mengkhawatirkan. Beberapa gejala seperti kecendrungan partai-partai hanya menjadikan pemilu sebagai ajang untuk memperoleh dan berbagi kekuasaan. Akibatnya kurang berfungsinya partai oposisi sebagai penyeimbang bagi partai yang sedang berkuasa. Terkadang juga demi kekuasaan, partai politik melakukan apa saja seperti aksi "perselingkuhan" di antara mereka demi kepentingan pragmatis. Untuk itu menurut Kuskridho gejala tersebut memperlihatkan gejala yang disebut dengan politik kartel. ${ }^{6}$

Politik kartel adalah politik di mana partai politik dan aktivitasnya tidak lagi mengusung kepentingan konstituen atau kepentingan publik tetapi mengurus diri sendiri dan politik menjadi profesi dalam dirinya ciri lainnya partai tak lagi mengusung program partai yang efektif, efisien dan pragmatis. Kecendrungan partai untuk secara samar-samar atau malu-malu melepas ideologi dasar bawaannya demi kepentingan yang lain; memelihara kerja sama dengan partai lain yang berbeda ideologi, memelihara akses sumber dana partai, dan lain-lain. Karena itu perbedaan ideologi dalam sistem politik kartel menjadi kabur. ${ }^{7}$

\footnotetext{
${ }^{5}$ Ibid, hlm.200-201

${ }^{6}$ Ibid, hlm. 182

${ }^{7}$ Ibid, hlm. 183
} 
Pelaksanaan fungsi dan tugas partai politik dari masa kemasa belum menunjukan keberhasilan yang signifikan. Pelaksanaan fungsi masih pada level menghasilkan suara yang sebesar-besarnya. Perolehan suara masih mendominasi paradigma berpikir dari elit politik. Apapun yang ingin dilakukan oleh partai politik berorientasi pada perolehan suara. Maka tidak mengherankan jika partai politik yang didukung oleh sistem kepartaian hanya menghasilkan perolehan suara. Untuk itu hampir disetiap level Pemilu apapun baik legislatif ataupun eksekutif pasti diwarnai suatu ketegangan karena kemenangan dihitung dari seberapa banyak suara yang diperoleh, setiap partai politik dapat dipastikan akan menggunakan semua cara agar mendapatkan suara yang banyak. Bahkan kegiatan yang bernuansa money politic pun dianggap sesuatu yang halal. Lantas tidakkah sangat sederhana fungsi ini? Setiap lima tahunan kita sebagai bangsa hanya disibukan dengan perseoalanpersoalan kecurangan dalam Pemilu, tidak kekerasan/kriminalitas, dan seterusnya.

Aturan mengatur fungsi rekrutmen politik dilakukan berdasarkan AD/ART partai politik yang bersangkutan. Akan tetapi kenyataannya hampir semua partai politik tidak mengatur pelaksanaan rekrutmen politik dalam AD/ART partai mereka akibatnya rekrutmen politik selama ini dilakukan secara pragmatis atau sesuai dengan kehendak atau keinginan dari elit parpol. Hal ini terindikasi salah satu sebabnya adalah ketiadaan prinsip rekrutmen politik tersebut akibatnya partai politik tidak mempunyai panduan atau pedoman untuk menyusun pola rekrutmen politik dalam AD/ART partai politik. Dengan demikian permasalahan yang hendak dikaji dalam tulisan ini adalah," Bagaimana mewujudkan prinsip umum rekrutmen politik sebagai landasan idill penyusunan pola rekrutmen dalam AD/ART partai politik?

\section{PEMBAHASAN DAN ANALISIS}

Istilah rekrutmen politik dalam konstitusi atau UUD 1945 tidak dikenal. Namun demikian terdapat pasal-pasal yang mengatur tentang pengisian jabatan atau seleksi pejabat negara. Menurut J.A.H. Logemann, pengisian jabatan merupakan salah satu persoalan pokok hukum tata negara. Negara sebagai organisasi jabatan, untuk itu jabatan dipandang sebagai pusat segala-galanya. 


\section{Jurnal Tripantang}

Falkultas Hukum Universitas Tamansiswa Palembang

Persoalan seputar jabatan antara lain mengenai penggadaan jabatan, penerimaan, cara menempatinya, peralihannya, berakhir dan penghapusan jabatan tersebut. Sedangkan metode penujukan jabatan meliputi pewarisan, pengangkatan, pemilihan dan penggantian jabatan secara bergiliran. ${ }^{8}$

Jabatan-jabatan dalam perspektif hukum tata negara dikenal dengan istilah jabatan publik. Secara harfiah, "publik office”tidak lain adalah jabatan publik atau jabatan umum, yaitu suatu posisi yang berhubungan dengan rakyat sebagai keseluruhan. Namun sebagai istilah hukum perkataan "publik office" dalam pengertian yang sempit biasanya dikaitkan dengan pengertian "pejabat negara" yang secara administratif ditentukan secara limitatif sebagai pejabat negara berdasarkan peraturan pemerintah yang khusus karena berhubungan dengan ketentuan mengenai hak administratif berupa tunjangan keuangan dan hak-hak protokoler. $^{9}$

Jabatan menurut perspektif hukum administrasi negara adalah lingkungan kerja awet dan digarisbatasi, dan yang disediakan untuk ditempati oleh pemangku jabatan yang ditunjuk dan disediakan untuk diwakili oleh mereka sebagai pribadi. ${ }^{10}$ Lingkungan kerja tersebut berisi fungsi-fungsi tertentu yang secara keseluruhan akan mencerminkan tujuan dan tata kerja organisasi. Sedangkan pemangku jabatan yaitu para pejabat yang merupakan orang perorangan (natuurlijkpersoon) yang duduk atau didudukkan dalam suatu jabatan dengan tugas dan wewenang untuk merealisasikan berbagai fungsi jabatan tertentu. ${ }^{11}$

Penentuan pejabat negara bukan semata-mata karena sifat kewenangannya, tetapi juga karena dasar hukum pembentukannya yang menyebutnya sebagai pejabat publik. Namun sayangnya, peraturan perundang-undangan tidak konsisten, dan terbakukan dalam menentukan mana institusi lembaga negara dan mana yang bukan. Penentuannya belum didasarkan atas kriteria baku, melainkan semata-mata bersifat normatif yaitu asal ditentukan dalam UU atau PP. Sedangkan secara umum,

\footnotetext{
${ }^{8}$ J.H.A. Logeman, Tentang Teorit Suatu Hukum Tata Negara Positif, Ichtiar Baru Van Hoeve, tanpa tahun., hlm. 130

${ }^{9}$ Jimly Asshiddiqie, Liberalisasi Sistem Pengisian Jabatan Publik, dalam buku Pengisian Jabatan Hakim Agung dan Hakim Konstitusi, PT RajaGrafindo Persada, Jakarta, 2016, hlm.4

${ }^{10}$ Ibid, hlm. 124

${ }^{11}$ Bagir Manaan, Teori dan Politik Konstitusi, FH UII Press, 2004, Hlm. 66
} 
melihat berbagai keputusan pengadilan di Amerika Serikat, pemegang jabatan publik ditentukan berdasarkan kewenangannya untuk membuat keputusan atas nama negara atau kepentingan publik. Jika jabatan dimaksud hanya bersifat “advisory (penasihat)" yang berisi pertimbangan yang tidak mengikat atau rekomendasi yang tidak memaksa dalam proses pengambilan keputusan, jabatan tersebut tidak dipandang sebagai "publik office" 12

Penentuan pejabat publik menurut ilmu politik digunakan istilah rekrutmen politik. Menurut Ramlan Surbakti (2003) bahwa rekrutmen politik adalah seleksi dan pemilihan atau seleksi pengangkatan seseorang atau sekelompok orang untuk melaksanakan sejumlah peranan dalam sistem politik pada umumnya dan pemerintahan pada khususnya. Rekrutmen merupakan kelanjutan dari fungsi mencari dan mempertahankan kekuasaan dan juga untuk mencari dan mengajak orang yang berbakat untuk turut aktif dalam kegiatan politik sebagai anggota partai politik dipandang sebagai lembaga politik yang melaksanakan rekrutmen politik. ${ }^{13}$

Istilah rekrutmen politik ini digunakan oleh UU No.2 Tahun 2011 tentang Partai Politik ketika mengatur tentang fungsi partai politik yaitu salah satu fungsinya tersebut adalah partai politik melakukan rekrutmen politik. Rekrutmen politik dimaksudkan untuk menyeleksi kader-kader pemimpin negara pada jenjang dan posisi tertentu. Kader-kader itu ada yang dipilih secara langsung oleh rakyat, ada pula yang dipilih melalui cara yang tidak langsung, seperti oleh DPR. Tidak semua jabatan melibatkan peranan partai politik, hanya jabatan yang bersifat politik saja (jabatan publik yang melibatkan partai politik) atau yang melibatkan peran partai poitik melalui prosedur politik. Untuk itu perlu dicermati perbedaan antara jabatan politis dengan jabatan teknik administratif dan karier. ${ }^{14}$

Secara khusus dalam konteks politik, rekrutmen politik sering merujuk pada seleksi kandidat (kandidasi), rekrutmen legislatif dan eksekutif. Menurut teori bahwa seleksi kandidat merupakan kunci dan tahap yang menentukan, karena dari proses rekrutmen itulah akan dihasilkan orang-orang yang akan menjadi wakil

\footnotetext{
${ }^{12}$ Ibid, hlm.5

${ }^{13}$ Komarudin Sahid, Memahami Sosiologi Politik, Ghalia Indonesia, Bogor, 2015 ,hlm.129

14 Anwar Rachman, Hukum Perselisihan Partai Politik, PT Gramedia Pustaka Utama, Jakarta, 2016, hlm. 98t
} 
rakyat dan siapa yang akan memerintah. Hasil tersebut tergantung pada proses yang digunakan, biasanya meliputi tiga tahap yaitu tahap sertifikasi, nominasi dan tahap pemilihan. Menurut Pippa Norris, tahap sertifikasi mencakup penentuan kriteria yang dikehendaki, aturan internal partai, aturan pemilihan, dan norma-norma sosial. Sementara tahap nominasi berkaitan dengan ketersediaan kader-kader partai yang memenuhi syarat dan posisi yang akan diisi. Tahap selanjutnya berkaitan dengan proses pemilihan, yang umumnya berkaitan dengan bagaimana cara memilih, siapa yang dilibatkan untuk memilih, dan bagaimana cara menentukan siapa yang menang. ${ }^{15}$

Pada sistem pengisian jabatan hanya ada dua hal penting. Pertama, apakah pengisian tersebut memerlukan atau tidak memerlukan partisipasi atau dukungan dari rakyat (publik); kedua, apakah pengisian jabatan tersebut harus dilakukan secara kolegial atau oleh perorangan tertentu, hal ini berkaitan dengan pertanggungjawaban dan pengawasan serta kendali terhadap pemangku jabatan atau jabatan tertentu. ${ }^{16}$

Pemangku jabatan disebut pejabat, dalam arti luas dibedakan antara pejabat yang diangkat (appointed officials) dan pejabat yang dipilih (elected official). Pejabat yang dipilih direkrut melalui proses (i) pemilihan langsung oleh rakyat, (ii) pemilihan langsung oleh rakyat tetapi tidak disebut sebagai pemilihan umum, (iii) pemilihan tidak langsung atau semi langsung yaitu melalui dewan pemilih, 'electoral collage' (iv) pemilihan tidak langsung melalui DPR. Sedangkan pejabat yang direkrut melalui pengangkatan adalah pejabat kepegawaian, baik sipil maupun militer, sebagaimana diatur dalam Undang-undang yang mengatur masing-masing dan dalam UU Nomor 5 Tahun 2014 tentang Aparatur Sipil Negara. ${ }^{17}$

Khusus mengenai pejabat-pejabat yang direkrut melalui pemilihan langsung oleh rakyat dalam praktik di Indonesia, meliputi; pasangan calon Presiden dan Wakil Presiden dalam pemilihan presiden, pasangan Gubernur dan Wakil Gubernur Kepala Daerah Provinsi selain Gubernur Daerah Istimewa Yogyakarta, pasangan

\footnotetext{
${ }^{15}$ Pippa Norris, Panduan Rekrutmen \& Kaderisasi Partai Politik Ideal di Indonesia, KPK \& LIPI, Jakarta, 2016, hlm. 10

${ }^{16}$ Ibid, hlm. 67

17 Jimly Asshiddiqie, Liberalisasi Sistem Pengisian......Op cit, hlm.10
} 
Bupati dan Wakil Bupati selain Bupati di Daerah Khusus Ibu Kota Jakarta, pasangan Walikota dan Wakil Walikota, selain Walikota di Daerah Khusus Ibukota Jakarta, anggota Dewan Perwakilan Rakyat (DPR), anggota Dewan Perwakilan Daerah (DPD), anggota Dewan Perwakilan Rakyat Daerah Provinsi (DPRD Provinsi), anggota Dewan Perwakilan Rakyat Daerah Kabupaten (DPRD Kabupaten) kecuali kabupaten administratif di Daerah Khusus Ibukota Jakarta, anggota Dewan Perwakilan Rakyat Daerah Kota (DPRD Kota) kecuali kota administratif di Daerah Khusus Ibukota Jakarta, dan Kepala Desa. ${ }^{18}$

Berdasarkan Pasal 22E ayat (3) UUD 1945 bahwa peserta pemilihan umum untuk memilih anggota DPR dan DPRD adalah partai politik. Begitupun dalam penentuan pasangan calon Presiden dan Calon Wakil Presiden dalam pemilihan presiden diusulkan oleh partai politik atau gabungan partai politik peserta pemilihan umum sebelum pelaksanaan pemilihan umum, sebagaimana diatur dalam Pasal 6A ayat (1) dan (2) UUD 1945. Sedangkan menurut Pasal 22E ayat (4) UUD 1945 peserta pemilihan umum untuk memilih anggota DPD adalah perseorangan, begitupun juga dengan peserta pemilihan kepala desa adalah perseorangan yang dijaring oleh Panitia Pemilihan sebagaimana diatur dalam Pasal 34 dan 35 UU Nomor 6 Tahun 2014 tentang Desa.

Pada pasal 223 dan 241 UU No. 7 Tahun 2017 tentang Pemilihan Umum diatur bahwa seleksi bakal calon Presiden dan Wakil Presiden serta calon anggota DPR dan DPRD dilakukan secara demokrasi dan terbuka sesuai dengan AD/ART dan atau peraturan internal partai politik peserta pemilu.

Untuk pemilihan Gubernur, Bupati dan Walikota dilakukan secara demokratis sesuai dengan Pasal 18 ayat (4) UUD 1945, sebagaimana pula diatur UU Nomor 8 Tahun 2015 tentang Perubahan Atas UU Nomor 1 Tahun 2015 tentang Perpu Nomor 1 Tahun 2014 tentang Pemilihan Gubernur, Bupati dan Walikota Menjadi Undang-undang bahwa pemilihan Gubernur, Bupati dan Walikota yang selanjutnya disebut Pemilihan adalah pelaksanaan kedaulatan rakyat di Provinsi dan Kabupaten/kota secara langsung dan demokratis. Pencalonan calon Gubernur, Bupati dan Walikota tersebut dilakukan oleh juga partai politik dan perseorangan.

${ }^{18}$ Ibid, hlm. 11 
Berdasarkan rumusan aturan tersebut maka pemilihan anggota DPR/DPRD, Presiden dan Wakil Presiden serta Kepala Daerah dilakukan dengan pemilihan secara langsung dengan mekanisme pencalonan dilakukan oleh partai politik. Dalam pasal 29 ayat (1a) UU No. 2 Tahun 2011 diatur bahwa rekrutmen dilaksanakan melalui seleksi kaderisasi secara demokratis sesuai dengan AD/ART partai dengan mempertimbangkan paling sedikit 30\% keterwakilan perempuan.

Sesuai dengan amanat Undang-undang tersebut, mekanisme pelaksanan proses rekrutmen politik tersebut diatur dalam AD/ART partai politik. Secara umum AD/ART partai politik mengatur bagaimana mengimplementasikan ideologi, visi, dan misi partai dalam bentuk aktivitas politik, sehingga isi AD/ART tersebut sangat khas. Namun demikian khusus yang terkait dengan rekrutmen politik sangat dibutuhkan pedoman atau konsep yang jelas sehingga terdapat kesatuan cara pandang antar partai politik dalam menentukan bakal calon pejabat publik atau pejabat politik tersebut. Contoh dalam Undang-undang tentang Pemilu diatur pencalonan bakal calon anggota DPR, DPRD, calon presiden dan calon wakil presiden serta calon kepala daerah dilakukan secara demokratis dan terbuka. Dalam penjelasanya dinyatakan cukup jelas, akibatnya Partai politik memiliki tafsiran yang bebas mengenai demokratis dan terbuka tersebut. Di sinilah peran konsep, prinsip dan asas hukum untuk membingkai pola rekrutmen tersebut agar tidak menjadi rekrutmen yang hanya berorientasi pada tujuan dan kepentingan partai politik semata atau menurut Paraniari Siahaan, ${ }^{19}$ terjadi disfungsi rekruitmen, karena proses rekruitmen selama ini didasarkan atas karir politik di partai politik, tawar menawar kepentingan, dan juga the money of candidate (mahar) bukan atas dasar the capability and credibility of candidate.

Bagi partai politik proses rekrutmen akan memberikan dampak yang baik untuk kemajuan suatu organisasi. Modal awal kemajuan organisasi terletak pada ketersediaan sumber daya manusia yang berkualitas. Kualitas diartikan terdidik sesuai dengan tugas atau kewajiban, atau mempuny pengalaman praktek atau fungsional. Serta dengan rekrutmen tersebut maka akan diseleksi kesesuaian antara

19 Pataniari Siahaan, Politik Hukum Pembentukan Undang-undang Pasca Amandemen UUD 1945, Konpress, Jakarta, 2012, hlm. 442-443 
karakter kandidat dengan sistem nilai dan ideologi partai politik. Sehingga akhirnya ideologi partai politik lah yang menentukan seorang kandidat diterima atau tidak sebagai anggota partai politik. ${ }^{20}$ Akan tetapi kenyataannya Undang-undang partai politik tidak menjadikan kaderisasi sebagai salah satu kewajiban yang harus dilaksanakan oleh partai politik sebagai badan hukum publik. Padahal, tanpa kegiatan kaderisasi berkala dengan sistem kaderisasi yang baku, parpol pada akhirnya tak lebih dari ormas berbaju 'partai politik'. ${ }^{21}$

Pippa Norris mengembangkan skema model dan menggambarkan faktorfaktor yang mempengaruhi proses rekrutmen partai politik untuk pencalonan dalam pemilu. Skema Norris terbagi atas tiga tahap yakni: sertifikasi, nominasi dan pemilu. Sertifikasi ini termasuk di antaranya aturan hukum pemilu, aturan partai dan norma sosial yang bersifat informal yang mendefinisikan kriteria kandidat yang dapat dicalonkan dalam pemilu. Nominasi adalah ketersediaan calon untuk dinominasikan dan proses di mana penyeleksi calon menentukan siapa yang akan dicalonkan dalam pemilu. Pemilu adalah langkah terakhir di mana kandidat memenangkan jabatan publik.

Menurut Norris dan Lovenduski, pola rekrutmen terbentuk atas hubungan antara ketersediaan kandidat yang mencari karir politik dan proses seleksi yang ditetapkan oleh partai politik. Terdapat dua pola rekrutmen partai politik, yaitu, pertama, pola vertical, yakni rekrutmen partai dilakukan secara hirarki dengan jalur struktural dalam organisasi partai. Dengan pola ini, organisasi partai memiliki kekuasaan dalam menentukan siapa kandidat yang tepat untuk mengisi jabatan politik. Pola ini biasanya sering disebut sebagai merit sistem. Merit sistem adalah sebuah proses rekrutmen yang didasarkan pada jenjang kaderisasi yang telah baku diterapkan pada suatu organisasi partai. Proses rekrutmen didasarkan pada keahlian, kemampuan, dan prestasi. Jenjang karier politik ditentukan atas dasar prestasi atau kinerja kader.

\footnotetext{
${ }^{20}$ Firmansyah, Mengelola Partai Politik, Yayasan Pustaka Obor Indonesia, Jakarta, 2011, hlm. 70

${ }^{21}$ Syamsudin Haris dkk, Panduan Rekrutmen \& Kaderisasi Partai Politik Ideal di Indonesia, KPK \& LIPI, Jakarta, 2016, hlm.49
} 
Kedua, pola lateral, yakni rekrutmen dibuka kepada semua individu, baik di dalam partai maupun di luar partai. Pola ini menekankan pada bekerjanya sistem organisasi partai secara demokratis, yang salah satunya dicirikan oleh kekuasaan yang terdesentralisasi. Proses rekrutmen dilakukan secara terdesentraliasi mulai dari pemilihan kandidat potensial di kepengurusan partai tingkat lokal yang terendah, hingga tingkat yang tertinggi. ${ }^{22}$

Berkaitan dengan seleksi di atas, proses kandidasi dan party selectorates secara teori ditipologikan menjadi dua yaitu yang bersifat ekslusif (tertutup) dan inklusif (terbuka). Proses penentuan tertutup dan terbuka menurut Kenig dan Rahat (2011) ditentukan oleh lima pihak yaitu pemilih, anggota partai, delegasi partai, kelompok partai parlemen, elit partai dan pucuk pimpinan partai. ${ }^{23}$

Pola Rekrutmen Politik, dalam kamus Bahasa Indonesia kata "pola" memiliki arti; gambar yang dipakai, corak, model, sistem cara kerja, dan bentuk (struktur) yang tetap. Sehingga kata "pola" dalam rekrutmen politik dimaksudkan untuk menentukan sistem, cara kerja dan bentuk dari masing-masing partai politik dalam menentukan rekrutmen politik untuk memilih atau menyeleksi kader, calon anggota legislatif, calon presiden dan wakil presiden, serta calon kepala daerah.

Ada tiga pertimbangan dalam proses rekrutmen politik. Pertama, rekrutmen politik merupakan indikator yang sensitif dalam melihat nilai-nilai dan distribusi pengaruh politik dalam sebuah masyarakat politik. Kedua, pola-pola rekrutmen politik merefleksikan sekaligus mempengaruhi masyarakat. Ketiga, pola-pola rekrutmen politik juga merupakan indikator yang penting untuk melihat pembangunan dan perubahan dalam sebuah masyarakat politik. $^{24}$

Dari sudut ketatanegaraan, rekrutmen politik merupakan salah satu bagian dari pilar yang akan dibangun untuk memperkokoh sistem ketatanegaraan. Ibarat bangunan, maka partai politik membutuhkan bahan baku yang berkualitas untuk menjadikan bangunannya kokoh dan kuat. Melalui rekrutmen politik diharapkan agar individu-individu dalam masyarakat menjadi individu yang berkualitas sehingga bisa ditempatkan pada posisi-posisi jabatan publik.

\footnotetext{
22 Ibid, hlm. 12

${ }^{23}$ Loc cit

${ }^{24}$ Komarudin Sahid, Op cit, hlm. 128
} 
Munculnya konsep persaingan dalam dunia politik telah mengubah peta perpolitikan dewasa ini. Partai politik harus menyadari bahwa keberadaan mereka tidak hanya satu atau dua partai politik akan tetapi banyak partai politik dimana semua partai politik tersebut harus memperebutkan dukungan atau suara dari masyarakat. Dukungan dan suara tersebut tidak mungkin datang begitusaja tanpa mengerahkan tenaga dan pikiran. Suara masyarakat atau rakyat menjadi fokus utama dalam persaingan politik. Masyarakat yang menentukan siapa pemenang dan siapa pecundang.

Sejatinya partai politik merupakan sarana bagi masyarakat untuk berpartisipasi dalam proses penyelenggaraan negara. Maka berdasarkan ini untuk menjamin terselenggaranya fungsi negara maka ada partai politik yang mendukung pemerintah dan ada partai politik sebagai penyeimbang pemerintah. Pakar politik ada yang membagi partai politik menjadi dua yaitu partai politik dalam parlemen dan partai politik di luar parlemen. Partai politik di dalam parlemen yaitu partai politik yang berhasil mendudukan kadernya di parlemen atau lembaga perwakilan atau lembaga legislatif. Sedangkan partai politik di luar parlemen yaitu partai politik yang bergerak di masyarakat sebagai basis massa di luar parlemen.

Terdapat peran strategis partai politik yang diberikan oleh konstitusi yaitu peran yang berkaitan dengan penyediaan calon pejabat publik. Peran strategis ini diatur kembali dalam Pasal 29 UU No. 2 Tahun 2011 tentang Partai Politik. Peran strategis ini diberikan dalam bentuk fungsi partai politik yaitu fungsi melakukan rekrutmen politik. Rekrutmen politik ini sangat dibutuhkan sebagai sarana penyediaan calon pejabat publik yang akan duduk di lembaga legislatif, maupun calon pejabat publik yang akan duduk di lembaga eksekutif.

Untuk menjalankan fungsi rekrutmen politik, partai politik membutuhkan prinsip-prinsip yang menjadi acuan sehingga rekrutmen politik itu menghasilkan pejabat yang berkualitas. Prinsip-prinsip ini muncul dari pentahapan rekrutmen politik yang dilakukan oleh partai politik selama ini.

\section{1). Prinsip Ketokohan}




\section{Jurnal Tripantang}

Falkultas Hukum Universitas Tamansiswa Palembang

Ketokohan lahir dari figuritas. Ketokohan selama ini telah membentuk suatu oligarki dan ini tidak sejalan dengan demokrasi. Namun demikian prinsip ketokohan ini tidak bisa begitu saja dihilangkan karena ini merupakan ciri khas masyarakat Indonesia. Untuk itu dalam hal ini ketokohan sebagai pola rekrutmen politik partai politik adalah ketokohan yang terbuka dan terencana. Siapapun tanpa masuk terlebih dahulu dalam oligarki dapat dicalonkan dengan memenuhi kriteriakriteria standar.

Bahwa Partai politik harus mampu untuk membentuk kader-kader yang akan menerima estapet kepemimpinan, partai politik harus mampu membentuk ketokohan dari kader-kader yang akan siap berkontribusi di dalam masyarakat, bangsa dan negara. Upaya pembentukan kader-kader politik tersebut telah diberikan kepada partai politik melalui pengkaderan dengan melakukan pendidikan politik ataupun pelatihan secara yang terencana, dan berkesinambungan. Melalui pendidikan politik ataupun pelatihan, partai politik harus mampu membuka kran sebesar-besarnya untuk menghadirkan kepemimpinan yang inspiratif dan bertanggung jawab.

Prinsip ketokohan ini melahirkan kriteria pejabat publik antara lain; 1) memiliki kepedulian terhadap perbaikan kehidupan masyarakat secara menyeluruh; 2) memiliki rasa tanggung jawab terhadap perbaikan kehidupan masyarakat secara kolektif; 3) tidak bersifat eksklusif; 4) amanah (menepati janji); 5) visioner; 6) sebagai pembela nasib rakyat.

Dedikasi dan integritas calon teruji dengan menempatkan mereka sebagai tokoh pemerintahan dan tokoh masyarakat. Ini juga untuk mempermudah "daya jual” di masyarakat. misalnya sebagai ketua RT, RW, Lurah ataupun Kepala Desa.

Di era digital saat ini, penokohan seorang tokoh diukur juga melalui survey elektabilitas pasangan calon. Dengan elektabilitas tokoh merupakan salah satu unsur perolehan suara. Dengan kata lain pasangan calon walaupun mendapat dukungan dari banyak partai atau partai besar belum memberi jaminan akan mendapatkan suara yang banyak. Sebagaimana yang dialami pada Pilgub Jabar 2018 yang dimenangi Ridwan Kamil hanya mengantongi 24 kursi dari PPP (9), 
PKB (7), NasDem (5) dan Hanura (3). Sedangkan pasangan Syaikhu mengantongi 27 kursi dari partai pengusung PKS (12), Gerindra (11), dan PAN (4).

Begitupun pada Pilgub Sulawesi Selatan 2018, sistem patron-klien tak terlepas dari kehidupan masyarakat Sulawesi yang mayoritas beretnis Bugis. Sistem itu menganalogikan kesetiakawanan antara seorang pemimpin dan pengikutnya. Spirit budaya itu telah menyebabkan mobilisasi, persaingan, ataupun kerja sama antarkelompok sosial, ikut terbawa dalam kontestasi Pilkada. ${ }^{25}$

Secara umum dapat dikatakan bahwa penokohan tokoh dilakukan oleh masyarakat (alamiah) dan dilakukan oleh partai politik (pembentukan). Penokohan secara alamiah terjadi karena keturunan yaitu berasal dari keluarga yang telah dikenal dan berjasa bagi masyarat setempat. Sedangkan penokohan oleh partai politik dilakukan melalui pembentukan atau pengkaderan.

\section{2). Prinsip Kemanfaatan/Demi Kepentingan Bersama}

Dalam kerangka multipartai, untuk menjaga kestabilan politik dan pemerintahan salah satu jalan yang dtempuh adalah koalisi partai politik. Setiap partai politik memiliki banyak perbedaan. Perbedaan tersebut telah diperlihatkan dengan ideologi partai politik yang tidak sama. Salah satu aspek yang dapat menyambungkan perbedaan tersebut adalah kemanfaatan. Keberadaan partai politik diarahkan untuk memberikan manfaat yang sebesar-besarnya terhadap masyarakat, bangsa dan negara. Prinsip kemanfaatan ini melihat siapa pun calon pemimpinnya yang lebih memberi manfaat bagi ummat dan mencegah mudharat yang lebih besar akan didukung

Menjelang penyelenggaraan Pilpres atau Pilkada, partai politik melakukan penjaringan pasangan calon. Salah satu konsekuensi dari multipartai adalah tidak adanya partai politik yang memiliki suara mayoritas atau di atas $25 \%$ akibatnya pencalonan presiden ataupun kepala daerah dilakukan dengan koalisi antar partaipolitik.

Dalam setiap pilpres maupun pilkada koalisi yang terbentuk tidak sematamata kerena faktor ideologi semata tetapi kemanfaatan bagaimana disampaikan

${ }^{25}$ Kolom politik \& hukum, Kompas, 11 Mei 2018 
Tifatul Sembiring bahwa koalisi PKS dengan partai manapun merupakan koalisi taktis atau tehnis. Dalam koalisi ini melihat siapa pun calon pemimpinnya yang lebih memberi manfaat bagi ummat dan mencegah mudharat yang lebih besar akan didukung.

Demi kemanfaatan bersama atau demi kepentingan, berdasarkan prinsip ini maka koalisi yang terbentuk merupakan koalisi lintas ideologi (kombinasi ideologi) seperti PKS-Gerindra (Islam dan Nasionalis), PKS-PDIP (Islam dan Nasionalis), PKS-Demokrat (Islam-Demokrat) dan seterusnya.

Prinsip kemanfaatan ini mendorong partai politik untuk "melepaskan baju ideologi" dengan menjadikan ideologi partai sebagai dasar menentukan standarisasi norma yang universal. Dengan standarisasi norma tersebut secara tidak langsung partai politik telah mengaktualisasikan ideologi partai politik ke dalam suatu norma yang mengikat koalisi ataupun oposisi partai politik.

\section{3.) Prinsip Ideologis}

Merupakan rekrutmen yang berdasarkan pada ideologi partai politik. Dalam sejarah kepartaian, ideologi partai politik secara garis besar dibagi pada ideologi berdasarkan agama, dan ideologi non agama seperti nasionalis, sosialis dan komunis. Pada perkembangannya ideologi berdasarkan agama diletakan pada garis kanan dan ideologi non agama diletakan sebelah kiri. Kecendrungan masyarakat sebagai partisipan dan pemilih tidak terlalu condong ke kanan dan tidak juga condong ke kiri. Untuk itu pada posisi di tengah ini diharapkan Pancasila sebagai titik temu dari ideologi partai tersebut.

Bahwa terdapat hubungan antara tipe partai dan atau pola rekrutmen politik, hal ini dapat dilihat dari visi/misi partai politik yang tercantum dalam AD/ART partai. Partai politik ideologis akan membentuk pola rekrutmen secara ideologis yang dicirikan dengan pola rekrutemen yang sistematis dan berjenjang, akan tetapi untuk partai politik non ideologis biasaya menggunakan standar umum dan ketentuan normatif, tidak berdasarkan pada pola rekrutemen yang tersistematis dan berjenjang 
Terkait ideologi partai politik tersebut, Evan melihat ada pembelahan ideologi yang dapat membedakan ideologi partai politik yaitu pembelahan kirikanan dan pembelahan atas-bawah. ${ }^{26}$ Evan menempatkan ideologi Islam dan nasionalis secara diametral (berhadap-hadapan). Artinya kedua ideologi tersebut pada Pemilu 2004 sampai Pemilu 2014 merupakan dua ideologi besar partai-partai politik di Indonesia. Walaupun demikian, pada garis tengah menunjukkan terjadinya percampuran ideologi pada tingkat dan kadar yang berbeda-beda. Artinya semakin dekat ke kanan, partai tersebut semakin kental dengan ideologi Islam, demikian pula kalau semakin dekat ke kiri, semakin kental dengan ideologi nasionalis. Sementara itu kalau semakin bergeser ke tengah-baik dari sisi kiri dan kanan tingkat kekentalan ideologinya relatif berkurang, dalam artai ada kemungkinan percampuran dengan ideologi lain. ${ }^{27}$

Dari pembelahan partai politik tersebut maka partai yang berada pada jarak ideologi kiri-kanan dan berada di tengah adalah Partai Demokrat, ideologi yang dikembangkan merupakan campuran antara Islam-Nasionalis sehingga ideologi yang diusung Nasionalis Religius. Sedangkan PKS, PPP, PAN dan PKB merupakan partai dengan symbol-simbolnya lebih dekat dengan Islam ketimbang Nasionalis. ${ }^{28}$

Untuk itu dapat dikatakan bahwa semakin modern pengorganisasian partai politik maka perbedaan idelogi antar partai politik akan semakin jelas hal ini ditunjukan dengan identifikasi atas identitas partai semakin terlihat. Pada tataran demokrasi modern keberadaan oposisi merupakan keharusan, karena demokrasi tidak menghendaki kesamaan tapi toleransi. Untuk itu dalam demokrasi, toleransi atas perbedaan adalah keharusan karena sudah fitrah manusia bahwa kita tidak sama.

Ideologi partai politik akan tergambar dari Figur pemimpin partai dan kader-kader partai. Salah satu fungsi ideology ini adalah untuk menjaga nilai-nilai yang dianggap baik yang menjadi sumber atau energy gerak bagi elit partai, pengurus partai maupun kader partai dalam menjalankan program yang telah

${ }^{26}$ Kevin Raymond Evan, The History of Political Parties and General Election In Indonesia, Arise Consultancies, Jakarta, 2003, hlm. 9-14

${ }^{27}$ Moch. Nurhasim, Masa Depan Partai Islam Era Reformasi, Op cit, hlm.19

${ }^{28}$ Ibid, hlm. 20 
tersusun secara terencana dan sistematis. Ideology ini juga menjadi "ruh" yang menghidupkan aktivitas politik partai menjadi aktivitas amal kebaikan kepada masyarakat bangsa dan Negara.

Pancasila sebagai falsafah bangsa dijadikan sebagai rujukan atau sumber ideologi bagi partai politik. Ideology yang dapat dilahirkan dari Pancasila antara lain; ideology berdasarkan agama (misalnya Islam), ideologi nasionalis, ideologi keadilan, dan ideologi sosialis (sosial).

Ideology partai politik ini selanjutnya akan melahirkan karakter dasar para kader partai, antara lain; karakter religius, karakter patriotik (nasionalis), karakter dermawan, karakter sederhana, karakter ramah menyenangkan dan karakter rendah hati.

\section{4). Prinsip Perimbangan Suara}

Bahwa penentuan koalisi partai politik ditentukan berdasarkan ambang batas perolehan suara. Salah satu dampak dari sistem multipartai adalah tidak tercapainya suara mayoritas partai politik. Dengan adanya koalisi untuk penentuan pejabat politik dilakukan melalui kompromi dan kesepakatan-kesepatan politik antar partai politik

Mahkamah Konstitusi (MK) memutuskan menolak uji materi pasal 222 UU No. 7 Tahun 2017 tentang Pemilihan Umum. Keputusan MK ini mensyaratkan ambang batas pencalonan presiden (presidential threshold) 20\% kursi DPR atau $25 \%$ suara sah nasional. Keputusan ini diperkirakan akan membuat peta pertarungan politik pada pemilihan presiden 2019 mengulang atau mirip dengan Pilpres 2014. Direktur Eksekutif Charta Politika, Yunarto Wijaya mengatakan, persyaratan pencalonan presiden ini hanya akan ada dua koalisi partai politik. ${ }^{29}$

Ketentuan ambang batas suara untuk pencalonan calon presiden dan calon wakil presiden serta pencalonan calon kepala daerah dan calon wakil kepala daerah telah menutup peluang bagi partai politik yang memiliki stok calon pejabat publik yang telah dilahirkan dari proses pengkaderan karena tidak memenuhi ambang

29 Ambang Batas Presiden 20\%, Pertarungan Pilpres 2019 akan mirip 2014, Dkatadata.co.id, 12 Januari 2018 
batas suara. Untuk itu ketentuan ambang batas ini harus proporsional. Ambang batas tersebut pada Pilpres tahun 2019 yang hanya mampu menghadirkan dua pasangan calon presiden dan calon wakil presiden dirasa belum mengakomodir aspirasi masyarakat. Maka dari itu ketentuan ambang batas ini perlu ditinjau ulang. Pluralisme masyarakat yang sangat majemuk setidaknya ada tiga pasangan calon yang dapat ditawarkan dalam Pilpres maupun Pilkada.

Dalam demokrasi perwakilan, keberadaan partai politik sangat menentukan terciptanya stabilitas negara dan stabilitas pemerintahan. Di satu sisi multipartai tidak dapat dielakkan karena pluralism masyarakat sebagai salah satu faktor penentunya. Di satu sisi lainnya sistem pemerintahan presidensial juga telah menjadi pilihan untuk menjalankan roda pemerintahan di Indonesia.

Sistem multipartai dalam sistem kepartaian di Indonesia telah memberikan konsekuensi tersendiri pada sistem pemerintahan presidensial. Hanta Yuda mengatakan rumusan sistem pemerintahan presidensial yang diamanatkan konstitusi UUD 1945 sulit dijabarkan secara normatif ketika dikombinasikan dengan struktur politik multipartai. Ketentuan normatif tersebut mengalami dilema dalam penerapannya sehingga perlu berkompromi dengan konteks realitas dalam seharian politik di Indonesia, khususnya keniscayaan sistem multipartai.(presidensialisme bersifat kompromis). ${ }^{30}$

Sistem multi partai merupakan suatu sistem dimana bentuk kepartaian terdapat lebih dari dua partai yang dominan, yang bersaingan, sebagai hasil dari pemilihan umum. Bentuk partai ini biasanya timbul sebagai akibat dari struktur masyarakat yang majemuk. Setiap golongan dalam masyarakat cendrung memelihara keterikatannya dengan asal usul budayanya lewat wadah politik. ${ }^{31}$

\section{Prinsip Demokrasi}

Ducan Watts mengartikan demokrasi dengan “...rule of or many people power with government resting on consent of the foverned. Sedangkan Abraham

\footnotetext{
${ }^{30}$ Hanta Yuda, Presidensialisme Setengah Hati: Dari Dilema ke Kompromi, Gramedia Pustaka Utama, Jakarta, 2010, hlm.235

${ }^{31}$ Moh. Mahfud MD, Politik Hukum di Indonesia, PT Raja GrafindoPersada, Jakarta, 2012, hlm. 394
} 


\section{Jurnal Tripantang}

Fakultas Hukum Universitas Tamansiswa Palembang

Lincoln "...government of the people, by the people and for the people....democracy is a sistem where no man is good enough to govern another man without that other's consent". Kalimat tersebut menegaskan bahwa demokrasi merupakan sebuah sistem di mana tidak seorang pun manusia cukup baik untuk memerintah manusia lainnya tanpa persetujuan mereka. ${ }^{32}$

Prinsip demokrasi ini ditujukan untuk mewujudkan rekrutmen politik secara demokratis. Terkait dengan rekrutmen politik, partai politik memahami demokrasi secara prosedural. Rekrutmen politik dilakukan melalui tahapan-tahapan. Tahapan pertama ditujukan untuk mendapatkan dukungan yang berasal dari internal partai (pemilihan umum internal) dan tahap kedua ditujukan untuk mendapatkan dukungan eksternal melalui Pemilu legislatif, Pemilu presiden dan Pemilihan kepala daerah. Seseorang yang akan dicalonkan atau direkrut untuk menduduki suatu jabatan publik terlebih dahulu harus mendapatkan dukungan dari internal dan juga dukungan eksternal. Untuk mendapatkan dukungan internal, seorang calon harus memenuhi persyaratan secara internal. Selanjutnya setelah persyaratan dipenuhi maka ditentukan beberapa kesepakatan-kesepakatan politik.

Sebagai sebuah sistem politik, demokrasi membutuhkan pranata sosial yang tepat agar demokrasi berjalan sesuai koridornya. Setidaknya ada tiga pranata sosial yang dibutuhkan untuk membangun demokrasi, yakni 1) individu-invidu/ partai politik yang berperan sebagai aktor politik, 2) aturan main yang jelas, egaliter dan transpartan untuk menjamin kebebasan sekaligus kesetaraan aktor-aktor politik tersebut dan 3) adanya kesadaran kolektif bahwa Pemilu merupakan metode untuk melakukan transfer kekuasaan. ${ }^{33}$

AD/ART menjadikan ruh demokrasi dalam penyusunan mekanisme rekrutmen politik sehingga pola rekrutmen secara demokratis melahirkan rekrutmen yang terbuka untuk siapa saja yang bersandarkan pada kriteria-kriteria umum sebagai standar seperti adanya jenjang pengkaderan, adanya pelatihan, adanya reward dan punishment .

\footnotetext{
${ }^{32}$ Firdaus, Constitutional Engineering; Desain Stabilitas Pemerintahan Demokrasi \& Sistem Kepartaian, Yrama Widya, Bandung, 2015, hlm.21

${ }^{33}$ Firmansyah, Persaingan, Legitimasi Kekuasaan, dan Marketing Politik Pembelajaran Politik Pemilu 2009, Jakarta; Yayasan Obor Indonesia, 2010, hlm. 36
} 


\section{Prinsip Keterbukaan/Tranparansi}

Transparansi merupakan keterbukaan dalam artian segala sesuatu dapat diketahui publik dan dapat dipertanggungajawabkan. Masing-masing partai politik memiliki pengertian dan cara pandang yang tidak sama dalam mewujudkan transparansi. Misalnya transparansi mengenai dana dan kesepakatan-kesepakatan politik antara individu dengan partai politik maupun antar partai politik. Transparansi dapat juga terlihat dalam transparansi nama-nama yang terdaftar dalam daftar calon yang akan direkrut. Berikut juga dengaan perolehan suara yang di dapat oleh masing-masing calon.

Transparansi juga menyentuh pada aktivitas-aktivitas dari para elit partai politik. masyarakat semakin terbuka dan perlu memahami bagaimana proses yang terjadi dalam gedung legislatif, seperti pembentukan fraksi dan komisi, pemilihan ketua DPRD dan penyusunan APBD. Lobi-lobi politik akan dapat dengan mudah diidentifikasi oleh para wartawan dan segera mempublikasikannya. Partai politik dan para politikus perlu memahami tuntutan masyarakat yang menyangkut semangat transparansi.

\section{Prinsip Keadilan}

Prinsip Keadilan ditujukan untuk mewujudkan rekrutmen politik yang berkeadilan. Dalam berbagai perspektif telah banyak disampaikan oleh para sarjana, filsuf maupun para ahli. Soerjono Soekanto melihat keadilan dalam hukum. Keadilan merupakan keseimbangan antara nilai kepastian dan nilai kesebandingan hukum.

Mengikuti prinsip keadilan dari Soerjono Soekanto, maka dalam rekrutmen politik harus menjamin kepastian tentang calon yang akan direkrut sesuai dengan prinsip-prinsip yang tidak bertentangan dengan ideologi partai. Serta calon yang akan direkrut secara visi misi dan tujuan sebanding dengan visi misi dan tujuan partai politik 


\section{Jurnal Tripantang}

Falkultas Hukum Universitas Tamansiswa Palembang

Rawls mengemukakan teori keadilan sebagai kesetaraan, maksudnya setiap pribadi memiliki hak yang setara terhadap sistem total yang paling luas bagi kebebasa-kebebasan dasar yang mirip dengan sistem kebebasan serupa bagi semuanya. ${ }^{34}$ Rawls berkeyakinan bahwa kebebasan hanya bisa dibatasi demi kebebasan itu sendiri, bukannya demi kepentingan perolehan ekonomi atau sosialnya. ${ }^{35}$

\section{Prinsip Kesetaraan/persamaan}

Prinsip kesetaraan berdasarkan persamaan dalam aturan ditujukan untuk mewujudkan rekrutmen politik yang berpihak gender. Kesetaraan atau persamaan merupakan condition sine qua non ( syarat mutlak) bagi demokrasi sebagai ideal. ${ }^{36}$ Dahl mengatakan bahwa persamaan mengandung nilai kemanusiaan, bahwa semua manusia sama, tidak ada yang lebih tinggi satu sama lain serta adalah baik jika manusia diperlakukan sama. ${ }^{37}$ Selanjutnya menurut retorika Dahl bahwa persamaan adalah untuk menjamin keterwakilan kepentingan seseorang/kelompok dalam pengambilan keputusan bersama. ${ }^{38}$

Prinsip kesetaraan dimaksudkan untuk menempatkan posisi calon dari kalangan perempuan yang sama dengan laki-laki. Kesamaan tersebut dilihat dari hak dan kewajiban calon baik dari perempuan dan laki-laki. Dalam Undang-undang partai politik kesetaraan tersebut dimaknai dengan pemenuhan kuota $30 \%$ untuk calon anggota perwakilan dari kalangan perempuan.

Tocqueville menyatakan; "ketika tiada seorangpun yang berbeda dari rekanrekannya, tiada seorang pun yang bisa menjalankan tirani; manusia akan bebas

\footnotetext{
${ }^{34}$ Ibid, hlm. 53

35 Ibid, hlm. 54

36 "The Ideal of democracy presupposes that political equality is desirable. Consequenty,
} if we believe in democracy as a goal or ideal, than implicitly we must view political equalty as a goal or ideal". Robert A. Dahl, On Political Equality, Yale University Press, New Haven, 2006, hlm. 2

37 "all human beings are of equal worth; that no person isintrinsically superior in worth to another; and that the good or interest of each person ought to be given equal consideration". Ibid, hlm. 131 2016, hlm.103

${ }^{38}$ Kuswanto, Konstitusionalitas Penyederhanaan Partai Politik, Setara Press, Malang, 
secara sempurna, karena mereka akan sepenuhnya setara; dan mereka semua akan setara secara sempurna, karena mereka akan sepenuhnya bebas. ${ }^{39}$

Hans Kelsen mengemukakan bahwa derajat kebebasan dalam masyarakat sebanding dengan jumlah individu yang merdeka yang mengandung arti bahwa semua individu mempunyai nilai politik yang sama dan bahwa setiap orang mempunyai tuntutan yang sama atas kebebasan, dan itu berarti bahwa, untuan yang sama sehingga kehendak kolektif selaras dengan kehendak individu, karena setiap orang mempunyai nilai politik yang sama. ${ }^{40}$

Terkait dengan peran wanita dalam politik, menurut Jumhur ulama sepakat akan haramnya wanita memegang kekuasaan dalam al-wilayatul kubro atau alimamatul-uzma (pemimpin tertinggi). Dimana wanita berperan sebagai pemimpin tertinggi dalam urusan pemerintahan. Akan tetapi dalam batas kepemimpinan dalam satu bidang tertentu yang tidak menyeluruh dalam masyarakat, wanita berhak mendapatkan itu, seperti di kejaksaan, pendidikan bahkan menjadi menteri dan anggota legislatif. ${ }^{41}$

\section{KESIMPULAN}

Pasal 29 UU No.2 Tahun 2011 telah mengamanatkan rekrutmen politik oleh partai politik dilakukan sesuai dengan AD/ART partai . secara tidak langsung dapat dikatakan bahwa AD/ART partai sebagai landasan yuridis bagi partai politik untuk melaksanakan fungsinya. Sebagai landasan yuridis, maka penyusunan pola rekrutmen politik dalam AD/ART partai tersebut harus memiliki landasan idil yang berupa asas-asas atau prinsip-prinsip umum penyusunan pola rekrutmen politik dalam AD/ART partai politik. Landasan idil tersebut berfungsi sebagai sumber materiil yang bersifat abstrak yang menentukan isi dari suatu norma. untuk itu perlu dijabarkan lebih lanjut dalam aturan yang konkrit seperti AD/ART partai.

\footnotetext{
${ }^{39}$ Ibid, hlm. 102.

${ }^{40}$ Hans Kelsen, Teori Hukum Murni, Dasar-Dasar Ilmu Hukum Normatif Sebagai Ilmu Hukum Empirik-Deskriptif, Alih Bahasa Somardi, RImdi Press, 1995, hlm. 287

${ }^{41}$ Surwandono, Pemikiran Politik Islam, hlm. 35
} 
Adapun prinsip-prinsip tersebut antara lain; prinsip ketokohan, prinsip kemanfaatan/kepentingan bersama, prinsip ideologis, prinsip perimbangan suara, prinsip demokrasi, prinsip keterbukaan, prinsip keadilan dan prinsip kesetaraan.

\section{DAFTAR PUSTAKA}

Asshiddiqie, Jimly, 2015, Penguatan Sistem Pemerintahan dan Peradilan, Jakarta; Sinar Grafika.

Armia, Mhd. Shiddiq Tgk., 2003, Perkembangan Pemikirn dalam Ilmu Hukum, Jakarta; PT Pradnya Paramita.

Busroh, Abu Daud,1993, Ilmu Negara, Bumi Aksara, Jakarta; Bumi Aksara

Budiardjo, Miriam, 2013, Dasar-Dasar Ilmu Politik, Jakarta; PT Gramedia Pustaka Utama.

Firdaus, 2015,Constitutional Engineering; Desain Stabilitas Pemerintahan Demokrasi \& Sistem Kepartaian, Bandung; Yrama Widya.

Firmansyah, 2010, Persaingan, Legitimasi Kekuasaan, dan Marketing Politik Pembelajaran Politik Pemilu 2009, Jakarta; Yayasan Obor Indonesia.

Firdaus, 2015, Desain Stabilitas Pemerintahan Demokrasi \& Sistem Kepartaian, Bandung; Yrama Widya.

Indrati, Maria Farida, 2007 Ilmu Perundang-undangan, Jenis, Fungsi dan Materi Muatan, Yogyakarta; Kanisius.

Kuswanto, 2016, Konstitusionalitas Penyederhanaan Partai Politik, Malang; Setara Press.

Kelsen, Hans, 1995, Teori Hukum Murni, Dasar-Dasar Ilmu Hukum Normatif Sebagai Ilmu Hukum Empirik-Deskriptif, Alih Bahasa Somardi, RImdi Press

Labolo, Muhadam dan Teguh Ilham, Partai Politik dan Sistem Pemilihan Umum di Indonesia Teori, Konsep dan Isu Strategis, Jakarta; PT RajaGrafindo Persada.

Lubis, Solly, 2009, Ilmu Pengetahuan Perundang-undangan, Bandung; Mandar Maju.

M.Setiadi, Elly \& Usman Kolip, 2013, Pengantar Sosiologi Politik, Kencana Jakarta; Prenadamedia Group.

Mertokusumo, Sudikno, 2007, Penemuan Hukum Sebuah Pengantar, Yogyakarta; Liberty.

Mahfud MD, Moh., 2012, Politik Hukum di Indonesia, Jakarta; PT Raja GrafindoPersada. 
Nuzul, Andi, 2016, Membangun Tata Hukum Nasional Perspektif Masyarakat pluralis, Yogyakarta; Trussmedia Grafika.

Salim dan Erlies Septiana Nurbani, 2014, Penerapan Teori Hukum pada Penelitian Disertasi dan Tesis, Jakarta, PT Raja Grafindo Persada.

Santoso, Listiyono, dkk, 2003, (de) Konstruksi Ideologi Negara, Jogjakarta; ningRat.

Yuda, Hanta, 2010, Presidensialisme Setengah Hati: Dari Dilema ke Kompromi, Jakarta; Gramedia Pustaka Utama. 